\title{
Early Medieval Spain
}

Unity in Diversity, 400-1000 


\title{
NEW STUDIES IN MEDIEVAL HISTORY
}

\author{
General Editor: Maurice Keen
}

Published

Roger Collins, Early Medieval Spain:

Unity in Diversity, 400-1000 (Second Edition)

Felipe Fernandez-Armesto, Before Columbus: Exploration and Colonisation from the Mediterranean to the Atlantic, 1229-1492

Alan Forey, The Military Orders from the

Twelfth to the Early Fourteenth Centuries

Michael Haren, Medieval Thought:

The Western Intellectual Tradition from Antiquity to the Thirteenth Century (Second Edition)

Edward James, The Origins of France:

From Clovis to the Capetians, 500-1000

Angus McKay, Spain in the Middle Ages:

From Frontier to Empire, 1000-1500

David Potter, A History of France, 1460-1560: The Emergence of a Nation State

Michael Richter, Medieval Ireland:

The Endurng Tradition

Forthcoming

Jeremy Johns, Early Medieval Sicily: Continuity and Change from the Vandals to Frederick II, 450-1250

Mark Whittow, The Making of Orthodox Byzantium, 600-1025 


\section{Early Medieval Spain}

Unity in Diversity, 400-1000

Second Edition

ROGER COLLINS

New Studies in Medieval History

MAURICE KEEN

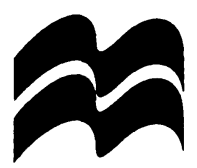


All rights reserved. No reproduction, copy or transmission of this publication may be made without written permission.

No paragraph of this publication may be reproduced, copied or transmitted save with written permission or in accordance with the provisions of the Copyright, Designs and Patents Act 1988, or under the terms of any licence permitting limited copying issued by the Copyright Licensing Agency, 90 Tottenham Court Road, London W1P 9HE.

Any person who does any unauthorised act in relation to this publication may be liable to criminal prosecution and civil claims for damages.

First edition 1983

Reprinted 1988, 1991

Second edition 1995

Published by

MACMILLAN PRESS LTD

Houndmills, Basingstoke, Hampshire RG21 2XS

and London

Companies and representatives

throughout the world

ISBN 978-0-333-64171-2

DOI 10.1007/978-1-349-24135-4

A catalogue record for this book is available from the British Library.

$\begin{array}{rrrrrrrrrr}10 & 9 & 8 & 7 & 6 & 5 & 4 & 3 & 2 & 1 \\ 04 & 03 & 02 & 01 & 00 & 99 & 98 & 97 & 96 & 95\end{array}$

\section{Series Standing Order (New Studies in Medieval History)}

If you would like to receive future titles in this series as they are published, you can make use of our standing order facility. To place a standing order please contact your bookseller or, in case of difficulty, write to us at the address below with your name and address and the name of the series. Please state with which title you wish to begin your standing order. (If you live outside the UK we may not have the rights for your area, in which case we will forward your order to the publisher concerned.)

Standing Order Service, Macmillan Distribution Ltd, Houndmills, Basingstoke, Hampshire, RG21 2XS, England 


\section{Contents}

List of Maps

Preface to the First Edition

vii

Preface to the Second Edition

ix

Chronological Table

$\mathrm{xi}$

Maps

xiii

xix

INTRODUCTION

The Roman Achievement 1

1 The Emergence of a New Order 11

The Roman Twilight 11

A False Start: The Kingdom of the Sueves 19

New Law and Old 24

2 The Imposition OF Unity 32

Divisions and Defeats $\quad 32$

Leovigild 41

3 A Church Triumphant $\quad 58$

4 The Seventh-Century Kingdom 87

Local Society in Town and Countryside $\quad 87$

The Rulers of the People 107

Outsiders and the Law 128

5 The Arab Conquest 144

The New Masters 144

Conquest and Society 151

$\begin{array}{ll}\text { Society and Government } & 169\end{array}$

6 The Umayad Regime 181

The Government of a Divided Society 181

The Land of Three Religions 198

7 The Christian Realms 222

The Asturias and León $\quad 222$

The Kingdom of Pamplona and the County of Aragón 246

The Frankish March in Catalonia 250 
Bibliographies $\quad 266$

A. Works in English 266

B. Works in Other Languages $\quad 272$

References $\quad 283$

Lists of Rulers $\quad 298$

Genealogical Tables $\quad 303$

Index $\quad 305$ 


\section{List of Maps}

1 The Roman Provinces of Spain c. AD400 xix

2 Bishoprics of the Visigothic Kingdom c. AD600 $\quad x x$

3 Al-Andalus and the Christian States in the Tenth Century

xxi

4 Castille, the Upper Ebro and the Kingdom of Pamplona in the Tenth Century

xxii

5 The Frankish Marches in Catalonia c. AD900

xxiii 


\section{Preface to the First Edition}

SPANISH history is not easy, and so it has perhaps been less popular outside of the Iberian peninsula than it deserves to be. For the medieval centuries the complications of a period unfamiliar, and inevitably alien in many aspects of its people's life and thought, are multiplied in Spain by the simultaneous existence of three, or occasionally more, Christian states, each with its own distinct history, culture and institutions, not to mention the one or more Muslim powers that dominated the south. In addition, the inescapable importance of the contributions of the Jewish and Basque communities only adds to the bewildering richness and complexity of the racial and cultural mix. However, neither the historian nor the inquiring general reader should be daunted by such a challenge, and indeed, it may be hoped that if they venture but a little way, they may be swept into sharing some of the enthusiasm of the small but devoted band of committed 'Hispanists'.

It has too long been assumed, and this again has been an excuse for neglect, that Spain, its history and culture, have been isolated from the mainstream of European development; that the peninsula has remained an exotic backwater, giving little, and little influenced by events beyond the Pyrenees. Yet in a world in which both Spain and Portugal have become members of the institutionalised European community, and in which their own creations, the states of Latin America, will come to play an increasingly prominent role, such an attitude is not only unjustified but also unwise. Nor, as will be seen, is it any more true of the Early Middle Ages, in which the study of the history of the peninsula leads us from the banks of the Danube to the deserts of Arabia. It may also be hoped that some consideration of the earlier history of Spain, of the continuities forced upon its peoples and their rulers by their past and by the geography of the land in which they live, will help in understanding the problems and aspirations of their modern successors.

A book on so limited a scale as this cannot hope to give a full and detailed treatment of all the subjects that need to be covered in the Early Medieval centuries of Spanish history. Selection is inescapable, and has to be essentially personal. My choice of topics and themes for extended treatment is in large measure a reflection of my own interests, though I have also been influenced by the prior existence of 
reasonable accounts in English of uncontroversial subjects, few as these have been, and to which reference is made in the first section of the Bibliography. However, despite the necessary limitations of this book in terms of size and in the providing of references, I hope to have avoided mere repetition of the conventional and received wisdom on the topics discussed. Even when space prevents the full elaboration of the alternative interpretations that I would seek to advance, I have preferred to give them, if only in outline, rather than to repeat more established views in which I have no confidence. Those already familiar with the subject may find the results unconventional, but possibly also challenging, either to approval or to disagreement. My own first interest in early Spanish history was aroused when, in another context, I read an article on one aspect of it, which so intrigued and also enraged me that I set to work to find out more, and have never stopped since. To its author, from whose many other writings I have gained much, both in provocation and in enlightenment, I remain forever grateful.

It was Denis Bethell who first suggested to me that I might write this book, and I greatly benefited from his advice and encouragement in the slow course of its composition. As editor and friend his untimely death was a sudden and terrible loss for all who knew him. I am most grateful to Maurice Keen, his successor in this series, for invaluable help in the final stages of preparation, and I should like to thank Sarah Mahaffy of the publishers, not least for her patience in waiting for the more than a little overdue completion of this work. However little this book may be a tribute to their skills, I should like to record my great debt to my teachers and mentors, Michael WallaceHadrill, Peter Brown and John Prestwich. From the correction of the numerous errors of spelling and punctuation to the discussion and clarifying of my ideas, this book has been aided and improved by my wife. The same could be said of its author. 


\section{Preface to the Second Edition}

THE twelve years that have passed since the first publication of this book have seen many developments in the study of Early Medieval Spanish history, both in Spain itself and more widely in Europe and the U.S.A. As part of the political and cultural changes that have affected the country since the end of the Franco period, there have been sweeping changes in the direction and in the methodologies of historical studies in Spain throughout the 1980s. A recognition that some of the questions being asked of the history of these centuries were too tied up with a set of ideological conflicts dating back to the late nineteenth century has proved liberating. Thus, the Visigothic kingdom is no longer condemned as 'decadent', and interest has veered sharply away from seeking moral explanations for such major and complex events as the Arab conquest of 711. In turn, however, new agendas have been adopted, in some cases being taken over uncritically from what are perceived to be the interests and objectives of other western European schools of historical study. Thus, the hunt for the causes of the 'decadence' of the Visigothic kingdom has given way to an equally pointless pursuit of the development of what is called 'protofeudalism'.

More generally, too, the change in the political climate has had a direct effect on what may be called historical fashion. The study of the Visigothic period, which seemed to be enjoying a vogue in the late 1970 s and early 1980 s has now gone into the doldrums, with relatively little new work being done on it. In part this must reflect a turning away from concern with a period in which the creation of a centralised and relatively authoritarian state, with a unitary ideology and rigid views on intellectual orthodoxy, forms the mainstay of historical inquiry. The Visigothic period's loss, however, has been the gain of the centuries that follow. The eighth to eleventh centuries have benefited from this change in fashion largely because their history can, and indeed must, be seen in terms of separate regional development. This coincides nicely with the contemporary pressure for increased provincial and regional autonomy. In some cases the study of a region's history in this period, carried out in its own major universities, will now be published in that region's own distinctive language or dialect. Even the history of the Arab-ruled south can serve modern ideological purposes, as evidenced by a graffito such as 
'iAndalucia, califato independiente!' on the walls of Córdoba. Such tendencies have made this period a particularly lively and exciting one in recent years, with works (not always easy for the outsider to track down) pouring out from regional academic presses. As in the case of the Visigothic period, this has been accompanied by a sense of the inadequacy of previous purely Hispanic historical agendas and methodologies, and in consequence by a turning outward for new aims and ways of study. Again, this has not always been uncritical: a wholesale adoption of the outward forms and jargon of French structuralist regional theses, à la Duby, Toubert, Guichard, etc. has not always been beneficial. Thin generalisation and lack of source criticism can vitiate the best of intentions. Where there has been genuine unalloyed progress, though, is in the field of medieval archaeology. The regular congresses and the publication of substantial reports by Spanish, French and German archaeologists working in the peninsula mark a series of real advances in the study of the material culture of many of the areas and periods covered in this book.

Some reflection of all of these developments will be found here. Changes and corrections have been incorporated throughout the book, and the central Chapter 5, on the Arab conquest and its effects, has been almost entirely rewritten and enlarged, to take account of recent research. Not the least important of the changes that have taken place over the last twelve years has been the publication of new and improved editions of many of the major texts relating to this period. The notes have therefore also been revised throughout, to refer to these new editions wherever possible and generally to incorporate reference to other significant recent work. A completely new bibliography replaces that in the previous edition, to provide signposts towards some of the new work mentioned above. So much has been done over the last decade that a comprehensive bibliographical essay would now be beyond the scope of this book. 


\section{Chronological Table}

376

378

381

395

406

407

408

415

417

418

$418-429$

$430-456$

456
Admission of the Visigoths into the Roman Empire by Valens

Visigothic revolt - Battle of Adrianople - accession of Theodosius I, from Spain

Death of Visigothic 'Judge' Athanaric - treaty made with Emperor Theodosius I

Death of Theodosius - Alaric becomes king of the Visigoths

Vandals, Sueves and Alans cross the Rhine; ravaging in Gaul 406-409 - army revolt in Britain

Elevation of Constantine III in Britain; leads troops into Gaul and becomes master of Spain in 408

Visigoths invade Italy

Vandals, Sueves and Alans cross Pyrenees

Visigothic sack of Rome - revolt of army in Spain against Constantine III

Vandals, Sueves and Alans established in Spain as

federates by rebel emperor Maximus - fall of

Constantine III - Visigoths move into Gaul

Visigoths control Barcelona

Visigoths campaigning in Spain for the emperor

against the Vandals and Alans

Visigoths withdraw to southern Aquitaine -

established there by treaty with the Empire, with

their capital at Toulouse

Hasding Vandals dominant power in Iberian

peninsula

Vandal defeat of Roman forces in southern Spain

Vandals invade Africa - establish kingdom there (429-533)

Suevic domination of the peninsula, except for

Tarraconensis - Mérida becomes their capital

Visigoths under Theoderic II invade Spain - defeat

and death of Suevic king Rechiarius - fragmented

Suevic kingdom driven back into the north-west of the peninsula 
466-484 Reign of Visigothic king Euric: completes conquest of Roman Spain

494, 497 Records of Visigothic settlement in Spain

506

507

511 Issue of the Breviary of Alaric - Council of Agde Battle of Vouillé: loss of most of the Visigothic realm in Gaul to the Franks

Renewed Frankish attacks - Visigothic kingdom comes under Ostrogothic rule until 526

II Toledo

Frankish attack on Visigothic Septimania - overthrow of King Amalaric as a result

Mid-sixth Period of weakness of royal authority and many

century revolts, e.g. local autonomy of Córdoba 550-572

Revolt of Athanagild against Agila leads to Byzantine intervention and their occupation of Cartagena and the south-east coast

$561 \quad$ I Braga - Suevic kingdom Catholic, partly due to work of Bishop Martin of Braga

567-590 Covered by Chronicle of John of Biclar, Bishop of Gerona

569-586 Reign of Leovigild: restoration of Visigothic royal power and unification of the peninsula, issue of law code, introduction of new regal styles, new coinage

569-572 Campaigns against the Byzantines, recovery of Córdoba

573-579 Campaigns against northern tribes and local rulers, foundation of Reccopolis

579-583 Revolt of Hermenigild

580

Arian Synod of Toledo - accentuation of religious conflict between Arians and Catholics

Suevic kingdom extinguished by Leovigild

587 Conversion of Reccared to Catholicism, under influence of Bishop Leander of Seville

589 III Toledo - formal conversion of the Visigothic kingdom

589-90 Suppression of Arian revolts - defeat of Frankish attack

599/600-636 Isidore Bishop of Seville

$610 \quad$ Synod of Toledo - Toledo recognised as metropolitan see of Carthaginiensis 
612-620 Reign of Sisebut: campaigns against the Basques and against the Byzantines, attempt to impose conversion of the Jews

624

631

633

654

$672 / 3$

$680-690$

680

694

711

$711-720$

718 or 722

720

721

729

$732 / 3$

$739-757$

c. 740

742-6/7 Continuing internal conflicts lead to the dictatorship of Yūsuf al-Fihri (747-756)

750

Final expulsion of the Byzantines king Dagobert I

IV Toledo ravaging in Ebro valley

Julian Bishop of Toledo against the Jews kingdom, other than in Narbonensis

Arab invasion - defeat of King Roderic the peninsula and in Septimania

Battle of Covadonga - establishment of governor As-Samh in battle at Toulouse in Cerdanya, allied to Duke Eudo of Aquitaine Poitiers

Reign of Alfonso I in the Asturias (741-742)
Usurpation of Sisenand with support of Frankish

Issue of the law code Forum Iudicum - Basque

Revolt of Paul in Narbonne against Wamba

Deposition of Wamba - Reign of Ervig: reissue of Forum Iudicum, with increased legislation directed

XVII Toledo: enslavement of all Jews in the

Survival of Visigothic kingdom in the north-east of independent Christian realm in the Asturias

Arab conquest of Barcelona and Narbonne

Arab expedition into Frankish Gaul - death of the

Suppression of revolt by Berber leader Munnus

Arab invasion of Aquitaine - defeat of the Aquitanians on the Garonne - defeat and death of the governor 'Abd al-Rahmān al-Ghāfiqi at battle of

Berber revolts in North Africa and in Spain arrival of Syrian forces in Spain leads to civil war

Overthrow of the Umayyad Caliphate of Damascus by the Abbāsids - one of the former dynasty, 'Abd al-Raḥmān, takes refuge in Africa 
'Abd al-Rahmān crosses to Spain and, with the aid of the opponents of Yüsuf, defeats him and establishes an independent state, the Umayyad Amirate

763 and 777 Failure of Abbasid inspired revolts against 'Abd al-Raḥmān I

776

778

Beatus of Liébana produced his Commentary on the Apocalypse

Charlemagne's expedition into the Ebro valley forced to withdraw from Zaragoza, his rearguard is destroyed by the Basques in the pass of Roncesvalles

791-842 Reign of Alfonso II in the Asturias: establishment of Oviedo as its capital, revival of Visigothic traditions in art and government, building of first church at Santiago de Compostela, contacts with the Frankish court

790s Adoptionist controversy

$801 \quad$ Frankish conquest of Barcelona - beginning of the 'Spanish march'

803 Revolt of the Banu Qasī in Tudela - suppressed

$806 \quad$ Frankish conquest of Pamplona

c. 808/10 Frankish failure to take Tortosa and hold Tarragona limits the extension of the new march Revolt against Frankish rule suppressed in Pamplona

Renewed revolt leads to the destruction of a Frankish army at the second Battle of Roncesvalles and the establishment of an independent kingdom in Pamplona

827 Barcelona held by Bernard of Septimania against Gothic rebels with Umayyad assistance

$839 \quad$ Council of Córdoba

844 First Viking raid on Spain - defeated by Ramiro I, but went on to sack Seville

c. 847-862 Ascendancy of Mūsa ibn Mūsa of the Banu Qasī in the upper Ebro; 'the third king of Spain' 
$848-849$

$851-859$

859

$866-910$

878

$880-917$

$886-912$

912-961

917-927

929-931

929

931-970

939

Mid-tenth century

Seizure of Barcelona by William, son of Bernard of Septimania (executed in 844) - suppressed by the forces of Charles the Bald The martyr movement in Córdoba Execution of Eulogius, titular Metropolitan of Toledo, its chief apologist - second Viking raid on coasts of Andalucia - they captured and ransomed King García of Pamplona - Defeat of Mūsa ibn Mūsa at Albelda by Ordoño I of the Asturias Reign of Alfonso III in the Asturias: beginning of Christian repopulation of the Duero valley and of Castille

Establishment of Wifred I 'the Hairy' as Count of Barcelona, which office becomes hereditary in his family

Ascendancy of muwallad rebel Omar ibn Hafsun, centred upon Bobastro

Reigns of Al-Mundhir and 'Abd-Allah in Córdoba: growing violence in the south between Arabs and indigenous converts to Islam (muwallads), many revolts and effectively independent states created in Mérida and other regions

Reign of 'Abd al-Rahmmann III: restoration of the authority of Córdoba, suppression of revolts and the greater imposition of authority over the Christian realms in the north of the peninsula Elimination of the sons of Ibn Hafsun

Suppression of revolt of the muwallad 'Abd al-Raḥmān al-jilliqi at Bádajoz

'Abd al-Rahmann III took the title of caliph

Fernán González Count of Castille

Battle of Simancas

Umayyad Spain at its apogee: a centre of learning, especially under the caliph Al-Hakam II, with its rulers extending their power to North Africa, frequent diplomatic exchanges with Byzantium and Ottonian Germany

Sancho I the Fat of León restored to his kingdom by the caliph 
966, 971

c. $980-1002$

985

988

997

998

$1002-1008$

$1009-1031$

1010

1031

1035

1037
Minor Viking raids

Ascendancy of Al-Manșūr in Córdoba

Barcelona sacked by Al-Manșūr

León, Zamora and Sahagún sacked by Al-Manșūr

Santiago sacked by Al-Manșūr

Al-Manșūr's son 'Abd al-Mālik established as his deputy in $\mathrm{Fez}$

On death of Al-Manșūr, 'Abd al-Mālik succeeded to his power, but on his death, possibly poisoned by his half-brother 'Sanchuelo', the dictatorial power of this dynasty of Viziers collapsed Almost continuous civil war around Córdoba between rival Umayyads and Hammūdids The Catalan expedition to Córdoba Extinction of the Umayyad dynasty and suppression of the caliphate

Death of Sancho 'the Great' of Pamplona-Navarre creation of a new kingdom of Aragon

Battle of Támara - unification of Castille and León under Fernando I 


\section{Maps}

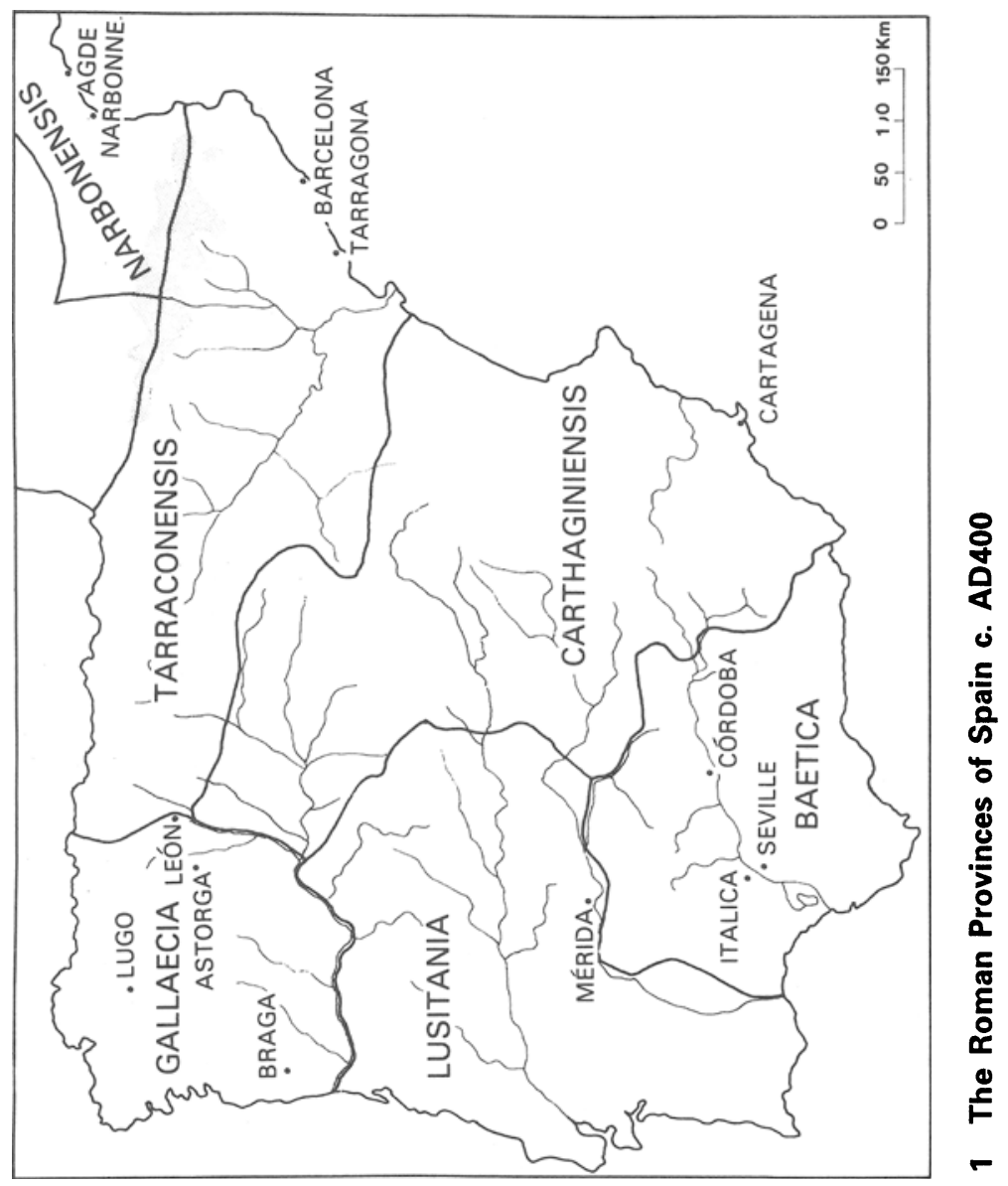




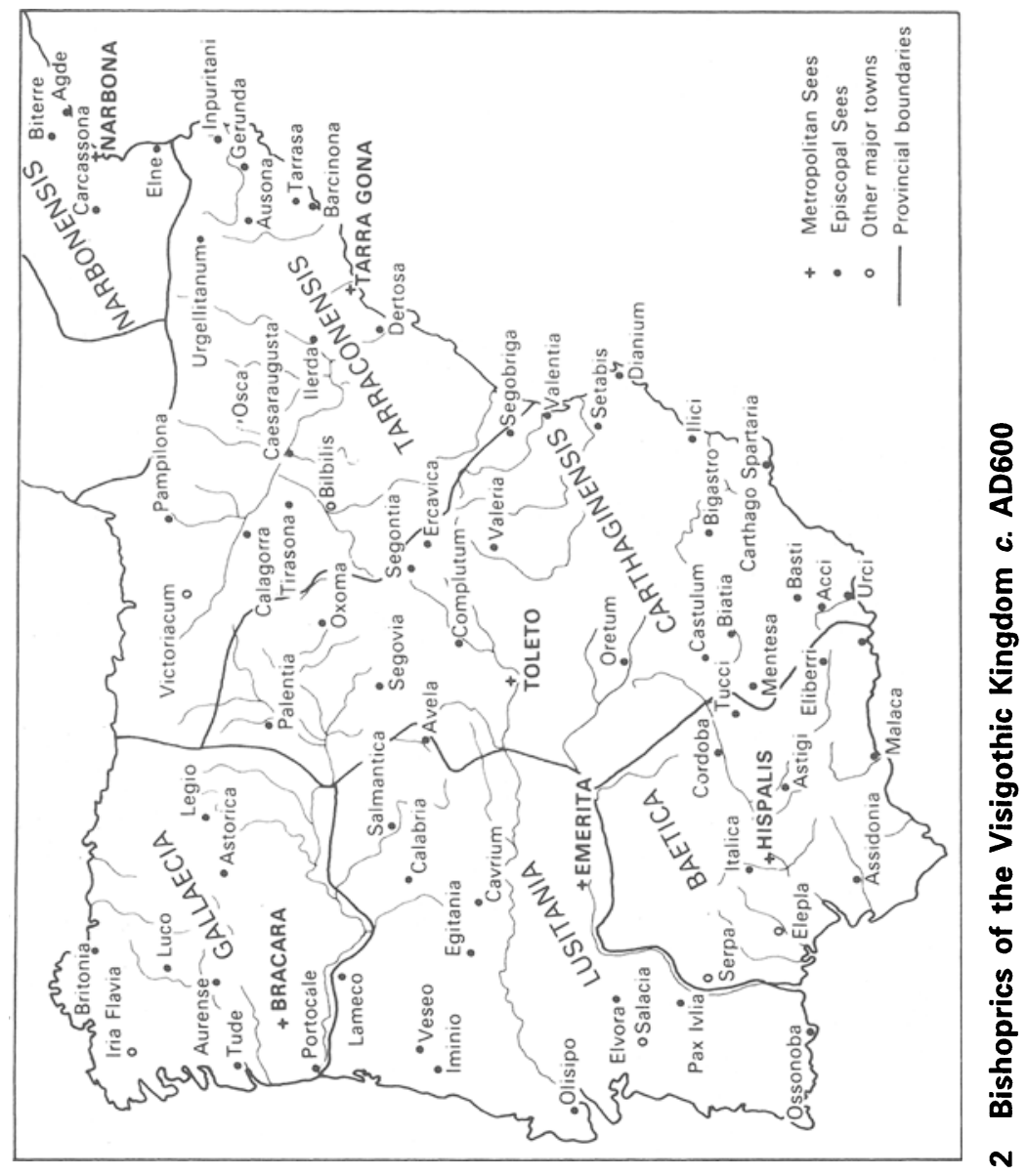




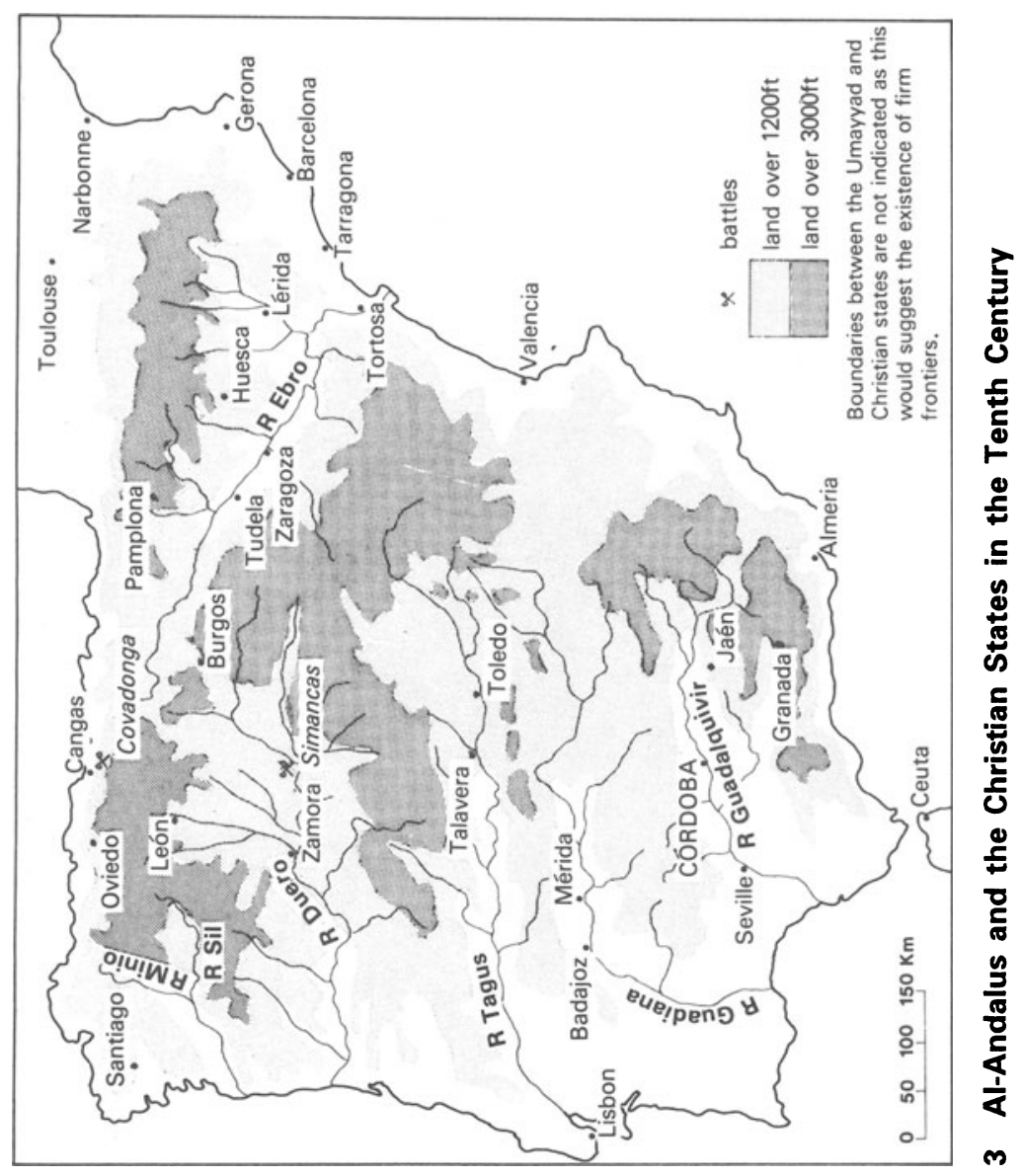



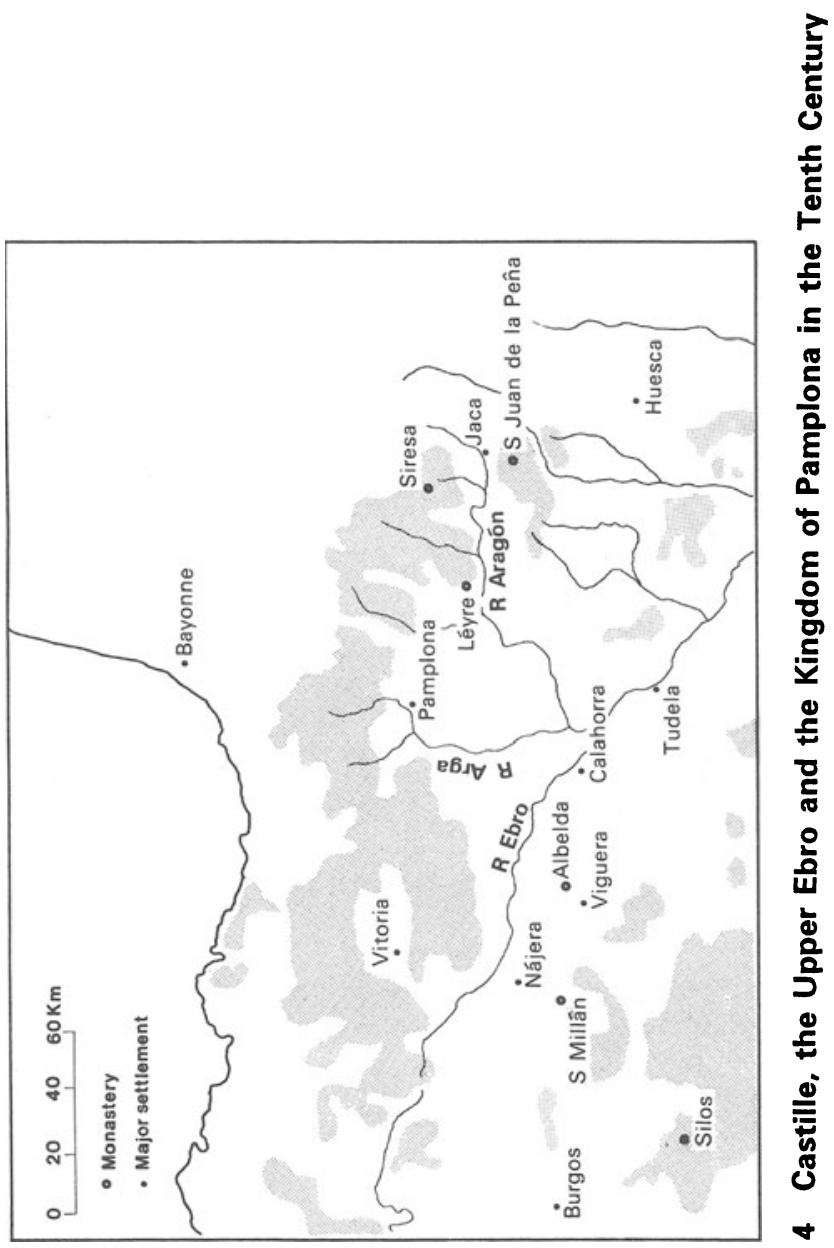


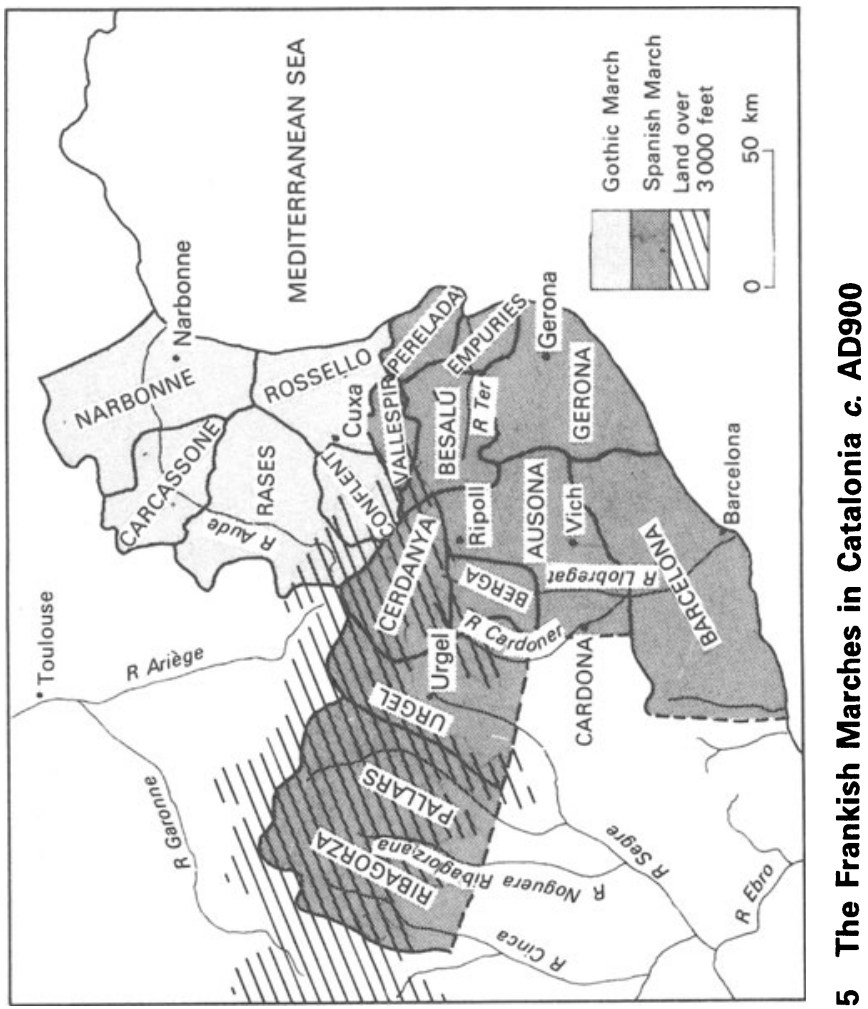


For Judith

and in Memory of Denis Bethell 